\title{
Changes in the phenology and composition of wine from Franconia, Germany
}

\author{
Anna Bock ${ }^{1, *}$, Tim Sparks ${ }^{1,2,3}$, Nicole Estrella ${ }^{1}$, Annette Menzel ${ }^{1}$ \\ ${ }^{1}$ Chair of Ecoclimatology, Technische Universität München, Hans-Carl-von-Carlowitz-Platz 2, 85354 Freising, Germany \\ ${ }^{2}$ Institute of Zoology, Poznań University of Life Sciences, Wojska Polskiego 71C, 60-625 Poznań, Poland \\ ${ }^{3}$ Department of Zoology, University of Cambridge, Downing Street, CB2 3EJ Cambridge, UK
}

\begin{abstract}
While the majority of the highest quality wine-producing regions in Western and Central Europe have benefitted from an increase in quality ratings due to climate change, traditional Franconian wine is in danger of losing its unique characteristics and its traditional spatial distribution. A long-term (1949 to 2010) study was made of reference vineyard observations in Lower Franconia, Germany. This wine region in the federal state of Bavaria is one of the most northerly in the world. The current climate requires the use of adapted grape varieties and has an impact on the unique quality of traditional Franconian wine. In this research, phenological events and intervals, and composition (acid and sugar content at harvest) of white grape cultivars (Müller-Thurgau, Riesling and Silvaner) were analysed for trends over time and relationships with potential climate drivers using multiple regression. Overall, the phenology of grapevines in Lower Franconia has tended towards earlier occurrence with a shortening of phenological intervals. The relative amounts of sugar in the grapes at harvest have tended to increase. Furthermore, the findings confirm a consistent relationship between onset dates of phenological phases and corresponding climate data. The grapevines were most influenced by mean maximum temperatures preceding the event, whereas precipitation and sunshine appeared less important. The observed warmer season results in greater ripening potential in grapes; as a consequence, the sugar content increases, while the acid component decreases, resulting in an altered wine typicity and quality. Thus, the balanced ratio of sugar and acid content shifts in favour of the sugar component, which may result in a loss of the traditional character of Franconian wine.
\end{abstract}

KEY WORDS: Viticulture $\cdot$ Phenology $\cdot$ Grapes $\cdot$ Composition $\cdot$ Sugar $\cdot$ Acid $\cdot$ Flowering $\cdot$ Harvest

\section{INTRODUCTION}

The increase of global temperature in recent decades and its effect on the environment were confirmed in the latest IPCC report (IPCC 2007). Several studies have described the impact of climate change on viticulture (Jones \& Davis 2000, Duchêne \& Schneider 2005, Jorquera-Fontena \& Orrego-Verdugo 2010, Malheiro et al. 2010, Urhausen et al. 2011), since climate is one of the key elements influencing grapevine yield and quality (van Leeuwen et al. 2004, Jones et al. 2005). In an earlier study of grapevine phenology in Bordeaux, Jones \& Davis (2000) observed an advance of phenological stages, a shortening of phenological intervals and an increase in potential wine quality, which a later study confirmed for other European wine regions (Jones et al. 2005). Global warming may also result in a shift in the distribution of grape cultivation, meaning that wine production might become profitable in regions formerly unsuitable or marginal for wine-growing (Lisek 2008). Most wine-producing regions in Western and Central Europe have benefitted from increasing temperatures, but the impact of global warming obviously varies according to the type of wine produced and the geographical location (Webb et al. 2007, Duchêne et al. 2010, Hall \& Jones 2010). East of the Rhine River, the northern limit of wine 
production turns gradually southward as the moderating influence of the Gulf Stream and surrounding seas decline. In comparison to other European wine regions, the more continental climate in some parts of Central Europe is characterized by shorter growing seasons, abundant spring and summer rain and cooler temperatures (Jackson 2000). Whereas increasing temperatures in these regions could lead to more consistent vintage quality, Jones et al. (2005) observed that they might be at, or close to, their optimum climate for producing the best quality wine with current grape cultivars.

The main wine-producing climate in Europe is found south of $50^{\circ} \mathrm{N}$ (Mullins et al. 1992), which makes German wine regions among the most northerly in the world. One of Germany's historical wine-producing regions is that of Lower Franconia in the federal state of Bavaria, where production dates back to the 8th century (Robinson 2006). The vineyards are located along the Main River, which has the effect of moderating temperature, while the steep hills receive maximum heat and light exposure, which enhances ripening (Jackson 2000). The cool conditions require the use of adapted grapevines (Vitis vinifera L.), which include frost resistant, latebudding and early maturing cultivars (Unwin 1991). Grape cultivars most commonly planted are MüllerThurgau, Riesling and Silvaner. These white cultivars are more suitable for cooler climates with less sunshine and earlier harvest (Robinson 2006). Approaching harvest, the relative amounts of sugar and acid found in the grapes are the main quality characteristics and are an indicator of grape ripeness. With an increase in the concentration of sugar, the organic acids decrease (Mullins et al. 1992). The absence of hot weather during ripening and the cool harvest conditions favour the retention of grape acidity, result in lower alcohol and promote the development or retention of varietal flavours. This gives the resulting wine a fresh taste and helps restrict microbial spoilage (Conde et al. 2007). Thus, the unique character or typicity (the characteristic of a wine that makes it typical for the region or cultivar of origin) is assured (Jackson 2000).

While the majority of the highest quality wine-producing regions in Western Europe and Germany have benefited from an increase in quality ratings (Malheiro et al. 2010), the impact of global warming on Franconian wine and its varietal typicity has received little attention.

Therefore, the objectives of the current work were to undertake a long-term study (1949 to 2010) to evaluate climate effects on grapevines in Lower
Franconia using reference vineyard observations. The study aims to estimate the effect of increased temperatures on grapevine phenology and composition. It assesses which, if any, variables have changed over the last $60 \mathrm{yr}$ and evaluates the potential future impacts on the local grape industry.

\section{MATERIALS AND METHODS}

\subsection{Grapevine data}

The present study analyses long-term time series of grapevine phenology and composition (acid and sugar content at harvest) of white grape cultivars in the wine-growing region of Würzburg in Lower Franconia, Germany ( $49^{\circ} 48^{\prime}$ N, $9^{\circ} 56^{\prime}$ E, Fig. 1). Phenology and composition were recorded for 3 main grape cultivars: Müller-Thurgau, Riesling and Silvaner. Records were obtained from vineyards located on hills adjacent to the Main River at an elevation of $\sim 220$ to $240 \mathrm{~m}$ and cover the period from 1949 to 2010.

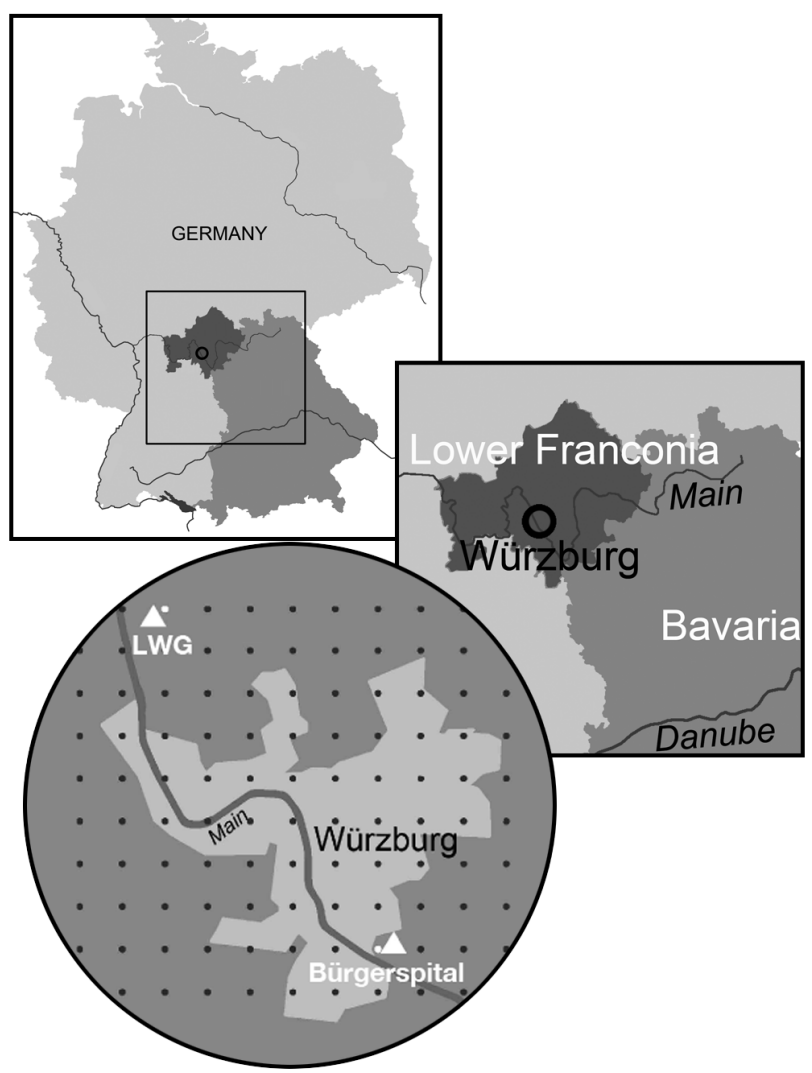

Fig. 1. Regional Office for Viticulture and Horticulture (LWG) and Bürgerspital vineyards used in this study $(\Delta)$. Black dots: $1 \times 1 \mathrm{~km}$ grid of climate data, white dots: grid points used in this study 
Two sources of vineyard data were used. The first time series was obtained from the Landesanstalt für Weinbau und Gartenbau (LWG; the regional office for viticulture and horticulture) in Veitshöchheim $\left(49^{\circ} 50^{\prime} \mathrm{N}, 9^{\circ} 52^{\prime} \mathrm{E}\right), \sim 6 \mathrm{~km}$ northwest of Würzburg. The LWG recorded phenophases from 1968 to 2010 using the BBCH (Biologische Bundesanstalt, Bundessortenamt and Chemical Industry) code (Meier 1997) for evaluating phenological stages. Records were made separately for the 3 grape cultivars. Over the whole recording period, observations came from the same group of vineyards, which are located at an elevation of $\sim 240 \mathrm{~m}$. Recorded phenophases included budburst (BBCH 09: green shoot tips clearly visible), full flowering (BBCH 65: 50\% of flowerhoods fallen), véraison (BBCH 81: colour change and initial maturation of the grape) and harvest (BBCH 89: berries ripe for harvest). Observations for Riesling and Silvaner between 1995 and 1999 were not available due to clearing and replanting, but full data were available for Müller-Thurgau. Sugar concentration measurements of the 3 cultivars were also recorded from 1949 to 2010. These measurements assist the grower to decide when to start harvesting. In order to make inter-annual and cultivar comparisons, the day of the year when a designated level $\left(60^{\circ} \mathrm{Oe}\right)$ was reached was abstracted. Degree Oechsle $\left({ }^{\circ} \mathrm{Oe}\right)$ measures the relative sweetness of the grape juice. This measurement indicates the specific weight of the must compared to the weight of water at a temperature of $20^{\circ} \mathrm{C}$ (Robinson 2006). Four phase intervals covering the development cycle of the grapevine were calculated from the phenological data (Duchêne \& Schneider 2005). These were (1) budburst to full flowering (development of the vegetative organs and flowers), (2) full flowering to véraison (accumulation of biomass, growth of berries, and colour change), (3) véraison to harvest (maturation of grapes), (4) growing season (estimated as budburst to harvest).

The second set of time series was obtained from the Bürgerspital zum Heiligen Geist winery. The vineyard is located at Abtsleite $\left(49^{\circ} 46^{\prime} \mathrm{N}, 9^{\circ} 57^{\prime} \mathrm{E}\right)$ at an elevation of $\sim 220 \mathrm{~m}, 3 \mathrm{~km}$ southeast of Würzburg. The winery kept records of budburst, beginning of flowering and end of flowering of the white Silvaner grapevine cultivar from 1970 to 2010. These events equate to $\mathrm{BBCH}$ codes 09, 61 and 69. Furthermore, the winery recorded general dates of the beginning and end of harvest, and the overall sugar content in all vineyards (i.e. of unspecified cultivars) from 1950 to 2010 . The total acid content $\left(\mathrm{g} \mathrm{l}^{-1}\right.$ ) was recorded from 1960 to 2010. To make the datasets of the LWG and the winery more comparable, the phenological phase full flowering (equating to $\mathrm{BBCH}$ 65) for the Bürgerspital vineyard was calculated as the average of the beginning and end of flowering. The development cycle of the Bürgerspital grapevines was subdivided into 5 intervals: (1) budburst to full flowering (Silvaner), (2) full flowering to harvest (full flowering of Silvaner to general harvest), (3) length of flowering (beginning to end of Silvaner flowering), (4) length of harvest (beginning to end of harvest), (5) growing season (Silvaner budburst to general harvest).

Please note that the time series on which the Bürgerspital intervals (2) and (5) are based do not derive from the same cultivar. Thus, these intervals may not be directly comparable with the intervals from the LWG.

For both data sources, a small number of apparently erroneous data were checked for plausibility (correlation with neighbouring phases or neighbouring observation sites) and obvious errors (e.g. 1 mo errors in recording the date) were corrected when necessary.

\subsection{Climate data}

The local climate stations were relocated several times over the study period, resulting in a variation in elevation $(\sim 97 \mathrm{~m})$ and location $(\sim 5 \mathrm{~km})$. Thus, the climate station time series cannot be regarded as homogenous. Moreover, the mesoclimate along the Main River is quite pronounced and differs from vineyard to vineyard, depending on the slope, exposition and elevation. Therefore, meteorological data on a $1 \times 1 \mathrm{~km}$ grid for each site were obtained from the Deutscher Wetterdienst (DWD: German Meteorological Service) and the mean of both grid points was used for further analysis in this study.

The data consisted of monthly observations of mean, maximum and minimum temperature (19482010), sum of precipitation (1948-2010) and sum of sunshine hours (1951-2010). Due to the absence of gridded daily observations, other climate variables and temperature derived indices (Duchêne \& Schneider 2005, Duchêne et al. 2010, Malheiro et al. 2010) were not used in this study.

\subsection{Statistical analysis}

Dates were converted to day of the year (DOY, $1=$ Jan 1, etc.) prior to analysis. Relationships between variables were explored using Pearson correlation coefficients. Residuals from regressions were tested 
to confirm normality (results not shown). Differences in mean values and slopes between cultivars and locations were tested using standard regression methods to test for equality of slopes (Draper \& Smith 1998).

Linear regression techniques were used to relate grapevine variables (phenology and composition) to year and climate variables. A stepwise methodology was applied to select the most significant climate predictors. Potential climate variables were restricted to those of the months preceding the mean date of the phenological event. However, because of the high number of potential climate variables and due to their collinearity, the selected coefficients must be interpreted with caution. Some predictors may appear in the final regression models by chance alone.

\section{RESULTS}

\subsection{Trends in phenology and composition}

The analysis of the phenology and composition time series for the LWG and the Bürgerspital are summarized in Table 1.

\subsubsection{LWG}

The mean budburst date of grapevine from the LWG did not differ significantly between cultivars and ranged from 30 April for Müller-Thurgau to 2 May for Riesling. Advances in budburst were too small (only 1 to $2 \mathrm{~d} \mathrm{decade}^{-1}$; Fig. 2a) to be detected as statistically significant.

The average dates for full flowering also did not differ significantly between cultivars and ranged between 22 June for Müller-Thurgau and 24 June for Riesling. Trends in the time series (i.e. advances in flowering) were very significant (all $p \leq 0.004$; Fig. 2b), by 3 to $4 \mathrm{~d}$ per decade. Mean véraison dates differed significantly between cultivars; the mean date for Müller-Thurgau was 11 August, Silvaner followed on 20 August and Riesling on 24 August. The average véraison dates became significantly earlier (all $\mathrm{p}<$ 0.001 ) for all cultivars, equating to 4 to $6 \mathrm{~d}_{\text {decade }}-1$ (Fig. 2c). The mean date on which the sugar content exceeded $60^{\circ} \mathrm{Oe}$ differed significantly between species and was earliest for Müller-Thurgau on 9 September and latest for Riesling on 21 September. The time series indicated a significant trend (all $p<0.001$ ) in all cultivars towards earlier ripening by 3 to $4 \mathrm{~d}$ decade $^{-1}$. Similarly, mean harvest dates differed significantly between species and ranged from 4 October for Müller-Thurgau to 22 October for Riesling. All cultivars were harvested significantly earlier (all $\mathrm{p}<$ 0.001, Fig. 2d) by 4 to 5 d decade $^{-1}$.

The phase interval of budburst to full flowering did not differ significantly between the 3 cultivars (Table 1). On average, the interval lasted 53 to $54 \mathrm{~d}$ and there were no significant trends over time in the length of the interval. The phase interval of full flowering to véraison differed significantly between cultivars and ranged from $50 \mathrm{~d}$ for Müller-Thurgau to $61 \mathrm{~d}$ for Riesling. Riesling and Silvaner cultivars had significant trends ( $p=0.026$ and 0.002 respectively) towards a shorter interval, equating to a change of 2 to $3 \mathrm{~d}_{\text {decade }}{ }^{-1}$ (Table 1, Fig. 3). The véraison to harvest interval differed significantly between species and averaged from $54 \mathrm{~d}$ for Müller-Thurgau to $58 \mathrm{~d}$ for Riesling. No significant trends towards a shortening of this phase were observed in any cultivar. The length of the growing season (budburst to harvest) also differed significantly between cultivars and ranged between 157 d for Müller-Thurgau to $168 \mathrm{~d}$ for Silvaner. Silvaner had a significant trend towards a shortening of the growing season $(p=0.030)$ by $3 \mathrm{~d}$ decade $^{-1}$. Trends for the other 2 cultivars were both negative but only marginally significant $(0.10>\mathrm{p}>$ 0.05; Table 1).

Trends did not differ significantly between the cultivars for any of the analysed variables.

\subsubsection{Bürgerspital}

Dates and composition recorded by the Bürgerspital showed similar values and trends as for the LWG (Table 1, Fig. 2a-b).

The mean budburst date of Silvaner during the study period of 1970 to 2010 was 30 April. As for LWG, the advance in budburst was too small to be detected as statistically significant (Fig. 2a). Full flowering averaged 20 June with the onset date advancing significantly ( $p=0.002$; Fig. $2 b$ ) by $4 d_{\text {decade }}$ d $^{-1}$. The general harvest of the winery from 1950 to 2010 began on average on 1 October and showed a significant trend ( $\mathrm{p}=0.008)$ towards earlier dates, advancing $2 \mathrm{~d}$ decade ${ }^{-1}$. The mean sugar content at harvest of 1950 to 2010 averaged $80.3^{\circ} \mathrm{Oe}$ and increased significantly $(\mathrm{p}<0.001)$ by $2.4^{\circ} \mathrm{Oe}$ decade $^{-1}$. The mean total acid content between 1960 and 2010 averaged $8.72 \mathrm{~g} \mathrm{l}^{-1}$ and displayed no significant trend.

The mean length of flowering of Silvaner was $8 \mathrm{~d}$. The length of harvest was on average $36 \mathrm{~d}$, covering 
Table 1. Franconian wine phenology and composition data. Where possible, data are presented for cultivars separately: M-T = Müller-Thurgau, R = Riesling, $\mathrm{S}=$ Silvaner, $\mathrm{u}=$ unspecified. LWG = Regional Office for Viticulture and Horticulture. Trends through time are summarized in the final 3 columns from regressions of the variable on year. $b=$ slope of regression coefficient. Significant results in bold $(\mathrm{p}<0.05)$. See footnotes for varying time periods

\begin{tabular}{|c|c|c|c|c|c|c|c|}
\hline & Cultivar & $\mathrm{n}$ & Mean & $\mathrm{SD}$ & $\mathrm{b}$ & $\mathrm{R}^{2}$ & $\mathrm{p}$ \\
\hline \multicolumn{8}{|l|}{ LWG 1968-2010 } \\
\hline \multirow[t]{3}{*}{ Budburst (date) } & $\mathrm{M}-\mathrm{T}$ & 43 & $30 \mathrm{Apr}$ & 9 & -0.17 & 0.06 & 0.122 \\
\hline & $\mathrm{R}$ & 38 & 2 May & 10 & -0.18 & 0.06 & 0.134 \\
\hline & $\mathrm{S}$ & 38 & 1 May & 9 & -0.16 & 0.05 & 0.190 \\
\hline \multirow[t]{3}{*}{ Full flowering (date) } & $\mathrm{M}-\mathrm{T}$ & 43 & 22 Jun & 9 & -0.36 & 0.24 & 0.001 \\
\hline & $\mathrm{R}$ & 38 & 24 Jun & 9 & -0.33 & 0.21 & 0.004 \\
\hline & $\mathrm{S}$ & 38 & 23 Jun & 10 & -0.34 & 0.21 & 0.004 \\
\hline \multirow[t]{3}{*}{ Véraison (date) } & $\mathrm{M}-\mathrm{T}$ & 43 & $11 \mathrm{Aug}$ & 9 & -0.42 & 0.35 & $<0.001$ \\
\hline & $\mathrm{R}$ & 38 & 24 Aug & 12 & -0.52 & 0.35 & $<0.001$ \\
\hline & $\mathrm{S}$ & 38 & 20 Aug & 13 & -0.60 & 0.37 & $<0.001$ \\
\hline \multirow[t]{3}{*}{$60^{\circ}$ Oe sugar content (date) } & $M-T^{A}$ & 61 & 9 Sep & 14 & -0.29 & 0.14 & 0.003 \\
\hline & $\mathrm{R}^{\mathrm{B}}$ & 56 & 21 Sep & 15 & -0.35 & 0.17 & 0.002 \\
\hline & $\mathrm{S}^{\mathrm{B}}$ & 56 & 18 Sep & 15 & -0.37 & 0.21 & $<0.001$ \\
\hline \multirow[t]{3}{*}{ Harvest (date) } & $\mathrm{M}-\mathrm{T}$ & 43 & 4 Oct & 9 & -0.42 & 0.34 & $<0.001$ \\
\hline & $\mathrm{R}$ & 38 & 22 Oct & 11 & -0.46 & 0.29 & $<0.001$ \\
\hline & $\mathrm{S}$ & 38 & 16 Oct & 11 & -0.48 & 0.31 & $<0.001$ \\
\hline \multirow[t]{3}{*}{ Budburst to full flowering (d) } & $\mathrm{M}-\mathrm{T}$ & 43 & 54 & 10 & -0.18 & 0.06 & 0.123 \\
\hline & $\mathrm{R}$ & 38 & 53 & 10 & -0.15 & 0.04 & 0.248 \\
\hline & $\mathrm{S}$ & 38 & 53 & 10 & -0.18 & 0.06 & 0.152 \\
\hline \multirow[t]{3}{*}{ Full flowering to véraison (d) } & $\mathrm{M}-\mathrm{T}$ & 43 & 50 & 5 & -0.06 & 0.02 & 0.324 \\
\hline & $\mathrm{R}$ & 38 & 61 & 7 & -0.19 & 0.13 & 0.026 \\
\hline & $\mathrm{S}$ & 38 & 59 & 7 & -0.27 & 0.23 & 0.002 \\
\hline \multirow[t]{3}{*}{ Véraison to harvest (d) } & $\mathrm{M}-\mathrm{T}$ & 43 & 54 & 6 & -0.00 & 0.00 & 0.991 \\
\hline & $\mathrm{R}$ & 38 & 58 & 8 & -0.08 & 0.02 & 0.446 \\
\hline & $\mathrm{S}$ & 38 & 56 & 7 & -0.14 & 0.06 & 0.140 \\
\hline \multicolumn{8}{|l|}{ Budburst to harvest (d) } \\
\hline \multirow[t]{3}{*}{ (growing season) } & $\mathrm{M}-\mathrm{T}$ & 43 & 157 & 10 & -0.24 & 0.09 & 0.056 \\
\hline & $\mathrm{R}$ & 38 & 172 & 12 & -0.26 & 0.09 & 0.073 \\
\hline & $\mathrm{S}$ & 38 & 168 & 11 & -0.31 & 0.12 & 0.030 \\
\hline \multicolumn{8}{|l|}{ Bürgerspital 1950-2010 } \\
\hline Budburst (date) ${ }^{\mathrm{D}}$ & $\mathrm{S}$ & 41 & $30 \mathrm{Apr}$ & 7 & -0.12 & 0.04 & 0.222 \\
\hline Beginning of flowering (date) ${ }^{\mathrm{D}}$ & $\mathrm{S}$ & 41 & 16 Jun & 9 & -0.36 & 0.24 & 0.001 \\
\hline Full flower (date) ${ }^{\mathrm{D}}$ & $\mathrm{S}$ & 41 & 20 Jun & 9 & -0.34 & 0.22 & 0.002 \\
\hline End of flowering (date) ${ }^{\mathrm{D}}$ & $\mathrm{S}$ & 41 & 24 Jun & 9 & -0.31 & 0.19 & 0.004 \\
\hline Beginning of harvest (date) & $\mathrm{u}$ & 61 & 1 Oct & 11 & -0.20 & 0.11 & 0.008 \\
\hline End of harvest (date) & $\mathrm{u}$ & 61 & $6 \mathrm{Nov}$ & 10 & -0.27 & 0.29 & $<0.001$ \\
\hline Length of flowering (d) ${ }^{D}$ & $\mathrm{~S}$ & 41 & 8 & 3 & 0.05 & 0.05 & 0.168 \\
\hline Length of harvest (d) & $\mathrm{u}$ & 61 & 36 & 9 & -0.09 & 0.03 & 0.175 \\
\hline Budburst to full flowering (d) ${ }^{D}$ & $\mathrm{~S}$ & 41 & 50 & 7 & -0.22 & 0.11 & 0.033 \\
\hline Full flower to harvest (d) D & $\mathrm{u}$ & 41 & 102 & 7 & -0.38 & 0.18 & 0.005 \\
\hline Budburst to harvest (d) ${ }^{\mathrm{D}}$ (growing season) & $\mathrm{u}$ & 41 & 152 & 9 & -0.30 & 0.15 & 0.013 \\
\hline Sugar $\left({ }^{\circ} \mathrm{Oe}\right)$ & $\mathrm{u}$ & 61 & 80.3 & 8.70 & 0.24 & 0.24 & $<0.001$ \\
\hline Acidity $\left(\mathrm{g} \mathrm{l}^{-1}\right)^{\mathrm{C}}$ & $\mathrm{u}$ & 50 & 8.7 & 1.96 & 0.01 & 0.00 & 0.699 \\
\hline
\end{tabular}

early to late vintages. No significant trends over time were observed for either interval. The phase interval of Silvaner budburst to full flowering lasted on average $50 \mathrm{~d}$ and was significantly $(\mathrm{p}=0.033)$ shortened by $2 \mathrm{~d}_{\text {decade }}{ }^{-1}$. The mean length of Silvaner full flowering to general harvest was $102 \mathrm{~d}$. A significant $(p=0.005)$ shortening of this phase interval of $4 \mathrm{~d} \mathrm{decade}^{-1}$ was observed. The Silvaner bud- burst to general harvest interval took on average $152 \mathrm{~d}$ and became significantly $(\mathrm{p}=0.013)$ shorter over the recording period, equating to $3 \mathrm{~d}$ earlier per decade.

Where direct comparisons with the LWG data were possible, e.g. in Silvaner budburst dates, no significant differences in trends or mean dates were detected. 

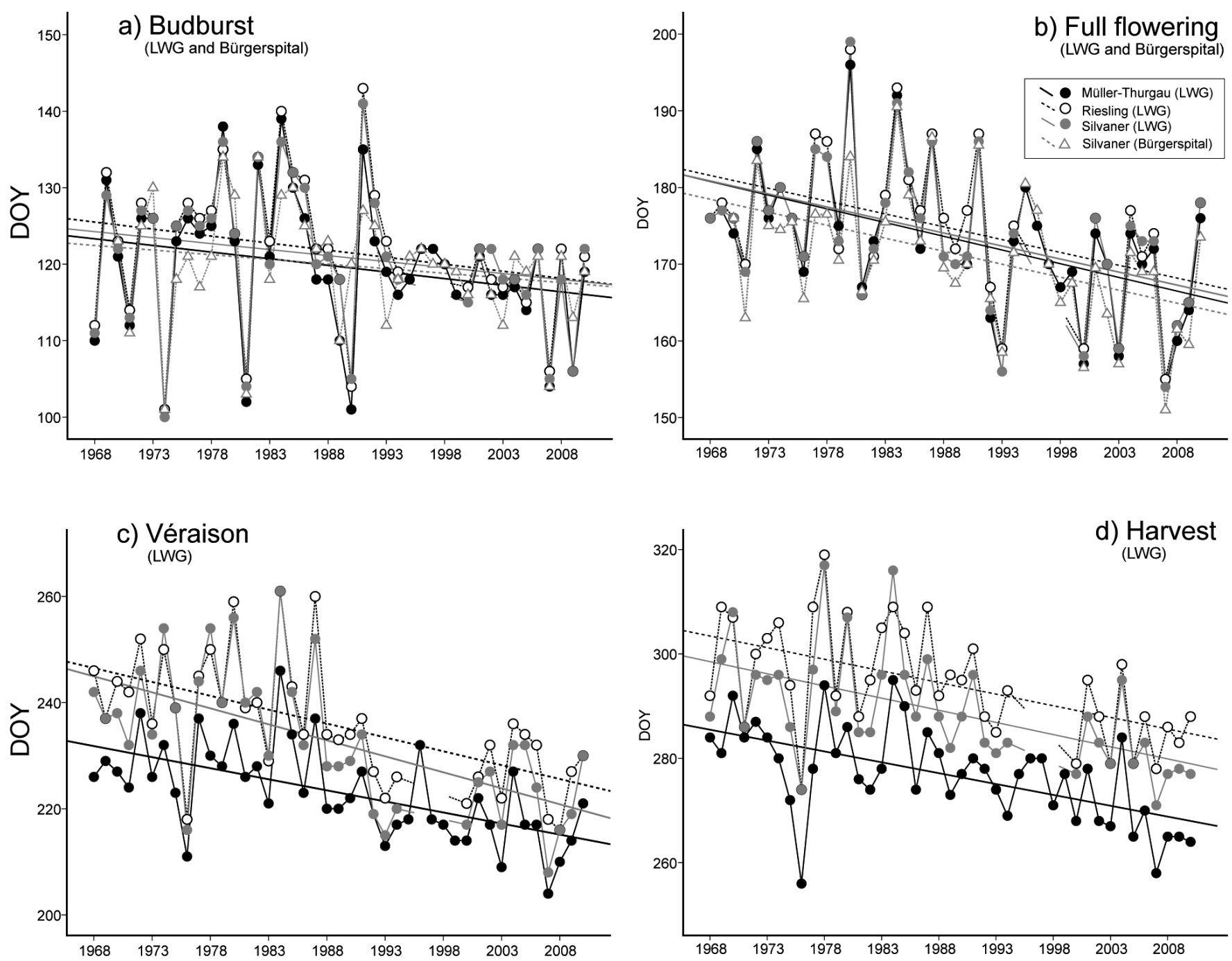

Fig. 2. Time series of the main phenological events of the grape varieties Müller-Thurgau, Riesling and Silvaner from the Regional Office for Viticulture and Horticulture (LWG), and Silvaner from Bürgerspital. DOY = day of year; regression lines superimposed. Note the different $y$-axis scales

\subsection{Relationships between phenophases and cultivars}

\subsubsection{LWG}

The phenological dates and composition of all 3 cultivars of the LWG showed significant positive relationships with preceding and subsequent phenological events (Table 2). Müller-Thurgau, Riesling and Silvaner showed, in general, highly significant $(\mathrm{p}<$ 0.001) correlations between full flowering, véraison and harvest dates with Pearson correlation coefficients of 0.66 to 0.86 . Furthermore, correlations of full flowering, véraison and harvest dates with the date when the sugar content reached $60^{\circ} \mathrm{Oe}$ were highly significant $(p<0.001)$ for all cultivars with correlation coefficients of 0.78 to 0.88 . Relationships between budburst dates and subsequent events showed significant $(\mathrm{p}<0.01)$ correlations with full flowering dates, while the correlation between budburst and véraison and harvest were weaker $(\mathrm{p}<0.05)$ or not significant. The only cultivar that displayed a significant correlation of budburst and véraison was Müller-Thurgau ( $\mathrm{r}=0.40, \mathrm{p}<0.01)$.

\subsubsection{Bürgerspital}

The relationship of the full flowering date of Silvaner with beginning of harvest, end of harvest and acid content showed highly significant $(p<0.001)$ positive relationships (Table 3). Meanwhile, full flowering had a significantly negative relationship 


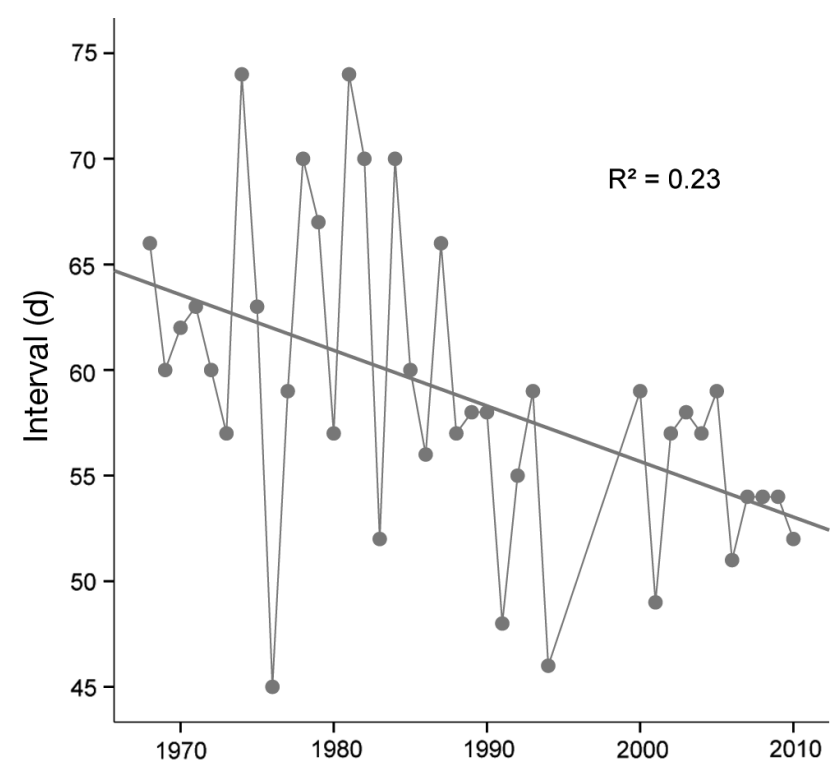

Fig. 3. Trend in the full flowering to véraison interval (1968-2010) for the cultivar Silvaner from the Regional Office for Viticulture and Horticulture (LWG)

with sugar content $(r=-0.76, \mathrm{p}<0.001)$. Furthermore, full flowering was positively related to budburst $(\mathrm{r}=0.54, \mathrm{p}<0.01)$. Acid levels showed large positive correlations with full flowering date whereas sugar content displayed a large negative correlation with these phenological events. Furthermore, sugar and acid content displayed a highly significant negative relationship with each other $(\mathrm{r}=-0.58, \mathrm{p}<$ $0.001)$.

\subsection{Effects of climate on phenology and composition}

Climate variables of the preceding months formed significant regression coefficients with the onset dates of phenological events and composition (Table 4). Minimum and mean temperatures are not reported since models including monthly maximum temperature generally displayed stronger relationships with grapevine phenology.

\subsection{1. $\mathrm{LWG}$}

Budburst of the 3 cultivars at the LWG was negatively related to the mean maximum temperatures of February and April. At a lower level of significance, budburst was furthermore negatively related to April precipitation. The timing of full flowering was influenced by the maximum temperature of the preceding months. An increase of $1^{\circ} \mathrm{C}$ during these months resulted in an advance of full flowering of $\sim 6 \mathrm{~d}$. For ease of display, Fig. 4 shows the relationships with mean maximum temperature from April to June.

Véraison timing was also highly responsive to temperature (Table 4), though the responses of Riesling appeared to be more dependent on temperature in later time periods (May to July). Silvaner véraison was the most responsive cultivar, advancing $9 \mathrm{~d}$ with an increase of $1^{\circ} \mathrm{C}$ during the months April to May.

Regression models for threshold dates on which the sugar content reached $60^{\circ}$ Oe were more complex than for the preceding phenological events with 68 to $89 \%$ of the variation being explained (Table 4 ). While the relationship to temperature (April to July) and September precipitation was highly significant for Riesling and Silvaner; Müller-Thurgau was more dependent on maximum temperature in June and sunshine hours in May and April.

\subsubsection{Bürgerspital}

Bürgerspital onset and composition values were associated with similar climate variables as LWG (Table 4). Silvaner budburst was influenced by March and April maximum temperatures. Full flowering was associated with the preceding 4 mo (i.e. March to June) and sunshine hours in March at a lower level of significance (Fig. 4). Both regression models were highly significant and explained $49 \%$ of the variation in budburst and $93 \%$ in full flowering onset dates.

The regression models for the beginning and end of harvest also showed that these events are highly responsive to maximum temperatures. An increase of temperature during March to July significantly advanced beginning of harvest dates. Precipitation and sunshine during March to April were included in the regression model, but were less significant. End of harvest furthermore displayed a positive relationship with July sunshine, indicating that increased sunshine delayed the end of harvest

For compositional variables, $74 \%$ of the variation in sugar content was explained by the regression model. Sugar content appeared highly responsive to temperature throughout the growing season. Furthermore, sunshine hours in March had an impact at a lower level of significance. Thus, increased temperature and sunshine hours resulted in an increase in sugar content. Regression models for acid content showed opposite relationships to those observed for sugar content. Increased temperatures during the 
Table 2. Pearson correlations between phenological phases of the 3 cultivars at the Regional Office for Viticulture and Horticulture (LWG; 1968-2010; see footnotes for varying time periods). The final 2 columns compare the same events between cultivars. ${ }^{*} \mathrm{p}<0.05,{ }^{* *} \mathrm{p}<0.01,{ }^{* * *} \mathrm{p}<0.001$

\begin{tabular}{|c|c|c|c|c|c|c|c|}
\hline & & Budburst & Full flowering & Véraison & Harvest & Silvaner & Riesling \\
\hline \multirow[t]{5}{*}{ Müller-Thurgau } & Budburst & & & & & $0.97^{* * *}$ & $0.98^{* * *}$ \\
\hline & Full flowering & $0.44^{* *}$ & & & & $0.99^{* * *}$ & $0.98^{* * *}$ \\
\hline & Véraison & $0.40^{* *}$ & $0.86^{* * *}$ & & & $0.93^{* * *}$ & $0.92^{* * *}$ \\
\hline & Harvest & $0.34^{*}$ & $0.66^{* * *}$ & $0.80^{* * *}$ & & $0.91^{* * *}$ & $0.82^{* * *}$ \\
\hline & $\begin{array}{l}60^{\circ} \text { Oe sugar } \\
\text { content (date) }{ }^{A}\end{array}$ & 0.27 & $0.80^{* * *}$ & $0.85^{* * *}$ & $0.78^{* * *}$ & $0.82^{* * *}$ & $0.85^{* * *}$ \\
\hline \multirow[t]{5}{*}{ Riesling } & Budburst & & & & & $0.99^{* * *}$ & \\
\hline & Full flowering & $0.43^{* *}$ & & & & $0.99^{* * *}$ & \\
\hline & Véraison & 0.22 & $0.81^{* * *}$ & & & $0.96^{* * *}$ & \\
\hline & Harvest & $0.36^{*}$ & $0.81^{* *}$ & $0.75^{* * *}$ & & $0.92^{* * *}$ & \\
\hline & $\begin{array}{l}60^{\circ} \text { Oe sugar } \\
\text { content (date) }{ }^{\mathrm{B}}\end{array}$ & $0.33^{*}$ & $0.83^{* * *}$ & $0.88^{* * *}$ & $0.82^{* * *}$ & $0.94^{* * *}$ & \\
\hline \multirow[t]{5}{*}{ Silvaner } & Budburst & & & & & & \\
\hline & Full flowering & $0.44^{* *}$ & & & & & \\
\hline & Véraison & 0.26 & $0.84^{* *}$ & & & & \\
\hline & Harvest & $0.37^{*}$ & $0.79^{* * *}$ & $0.82^{* * *}$ & & & \\
\hline & $\begin{array}{l}60^{\circ} \mathrm{Oe} \text { sugar } \\
\text { content (date) }\end{array}$ & $0.40^{*}$ & $0.82^{* * *}$ & $0.84^{* * *}$ & $0.85^{* * *}$ & & \\
\hline \multicolumn{8}{|c|}{${ }^{\mathrm{A}} 1949-2010,{ }^{\mathrm{B}} 1950-2010$} \\
\hline
\end{tabular}

Table 3. Pearson correlations between phenological phases of grapes at Bürgerspital and compositional variables (sugar, acidity). $\mathrm{S}=$ Silvaner, $\mathrm{u}=$ unspecified. ${ }^{*} \mathrm{p}<0.05,{ }^{* *} \mathrm{p}<0.01,{ }^{* * *} \mathrm{p}<0.001$. See footnotes for time periods

\begin{tabular}{|c|c|c|c|c|c|c|c|}
\hline & $\begin{array}{l}\text { Budburst } \\
\text { (S) }{ }^{C}\end{array}$ & $\begin{array}{l}\text { Beginning } \\
\text { of flowering } \\
\text { (S) }{ }^{C}\end{array}$ & $\begin{array}{l}\text { Full } \\
\text { flowering } \\
(\mathrm{S})^{\mathrm{C}}\end{array}$ & $\begin{array}{l}\text { End of } \\
\text { flowering } \\
\text { (S) }{ }^{\mathrm{C}}\end{array}$ & $\begin{array}{l}\text { Beginning } \\
\text { of harvest } \\
\text { (u) }\end{array}$ & $\begin{array}{c}\text { End of } \\
\text { harvest } \\
\text { (u) }{ }^{\mathrm{A}}\end{array}$ & $\begin{array}{c}\text { Sugar } \\
\text { content } \\
\text { (u) }{ }^{\mathrm{A}}\end{array}$ \\
\hline Beginning of flowering $(\mathrm{S})^{\mathrm{C}}$ & $0.51^{*}$ & & & & & & \\
\hline Full flowering $(\mathrm{S})^{\mathrm{C}}$ & $0.54^{*}$ & $0.99^{* * *}$ & & & & & \\
\hline End of flowering $(\mathrm{S})^{\mathrm{C}}$ & $0.55^{* * *}$ & $0.95^{* * *}$ & $0.99^{* * *}$ & & & & \\
\hline Beginning of harvest $(\mathrm{u})^{\mathrm{A}}$ & $0.29^{* *}$ & $0.69^{* * *}$ & $0.71^{* * *}$ & $0.71^{* * *}$ & & & \\
\hline End of harvest $(\mathrm{u})^{\mathrm{A}}$ & $0.34^{*}$ & $0.59^{* * *}$ & $0.60^{* * *}$ & $0.60^{* * *}$ & $0.60^{* * *}$ & & \\
\hline Sugar content $(\mathrm{u})^{\mathrm{A}}$ & $-0.35^{*}$ & $-0.75^{* * *}$ & $-0.76^{* * *}$ & $-0.76^{* * *}$ & $-0.50^{* * *}$ & $-0.59^{* * *}$ & \\
\hline Acid content $(\mathrm{u})^{\mathrm{B}}$ & 0.21 & $0.58^{* * *}$ & $0.61^{* * *}$ & $0.62^{* * *}$ & 0.22 & 0.17 & $-0.58^{* * *}$ \\
\hline \multicolumn{8}{|c|}{${ }^{\mathrm{A}} 1950-2010,{ }^{\mathrm{B}} 1960-2010,{ }^{\mathrm{C}} 1970-2010$} \\
\hline
\end{tabular}

growing season (i.e. April to October) had a significant negative impact on the acid content, but only explained $28 \%$ of the variation (Fig. 5). Furthermore, the full regression model shows that acid content also seemed to respond negatively to sunshine hours (i.e. a decrease in acid content), while precipitation had a positive effect ( $78 \%$ total variation explained).

\section{DISCUSSION}

\subsection{Trends through time}

Overall, grapevines in Lower Franconia have shown trends toward earlier phenological events, a shortening of phase intervals and increases in sugar content over the recording periods. The trends over time in this study conform, in general, to results of other long term studies (Jones \& Davis 2000, Duchêne \& Schneider 2005, Webb et al. 2007, 2011, de Orduna 2010).

Jones \& Davis (2000) discovered an advance of budburst, flowering, véraison and harvest in Bordeaux for the period of 1952 to 1997, though harvest date was the only series that had a significant trend, advancing 2.8 d decade $^{-1}$. In Alsace (eastern France), all of the phenological events advanced significantly since 1965 (Duchêne \& Schneider 2005). Budburst and flowering advanced by $4 \mathrm{~d}$ decade ${ }^{-1}$, véraison by $7 \mathrm{~d}_{\text {decade }}{ }^{-1}$. In the Mosel Valley $(\sim 240 \mathrm{~km}$ west of Würzburg), budburst and flowering advanced $\sim 2 \mathrm{~d}$ decade $^{-1}$ (Urhausen et al. 2011). 


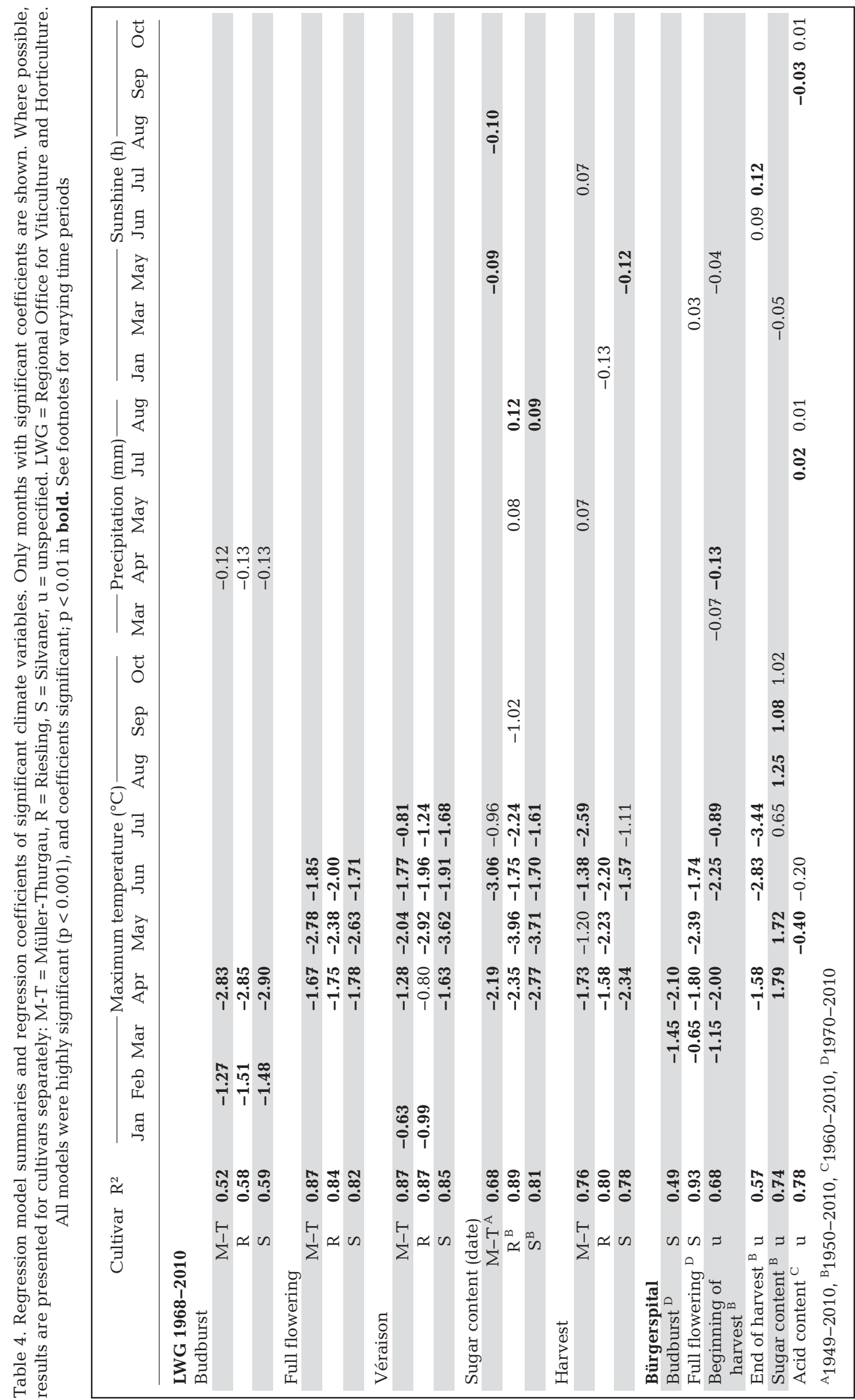




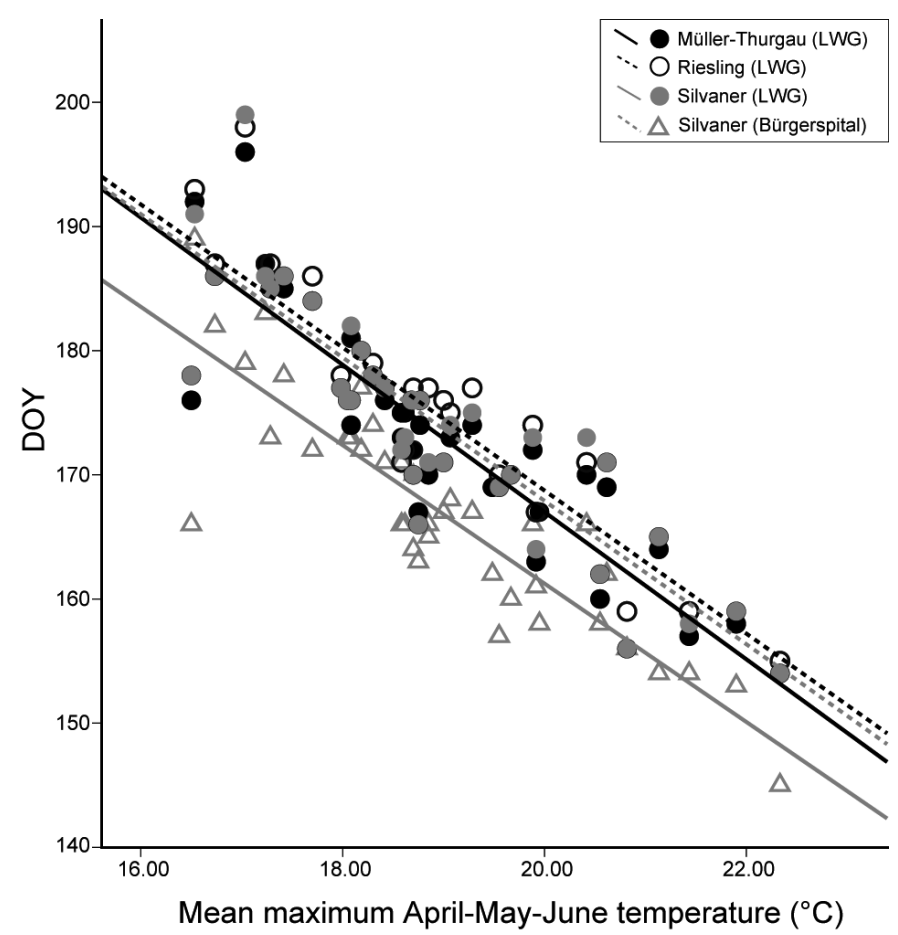

Fig. 4. Relationships between full flowering date and mean maximum April-May-June temperature. $\mathrm{R}^{2}=0.81,0.79$ and 0.78 for Müller-Thurgau, Riesling and Silvaner, respectively, from the Regional Office for Viticulture and Horticulture $(\mathrm{LWG})$; and $\mathrm{R}^{2}=0.79$ for Silvaner from Bürgerspital

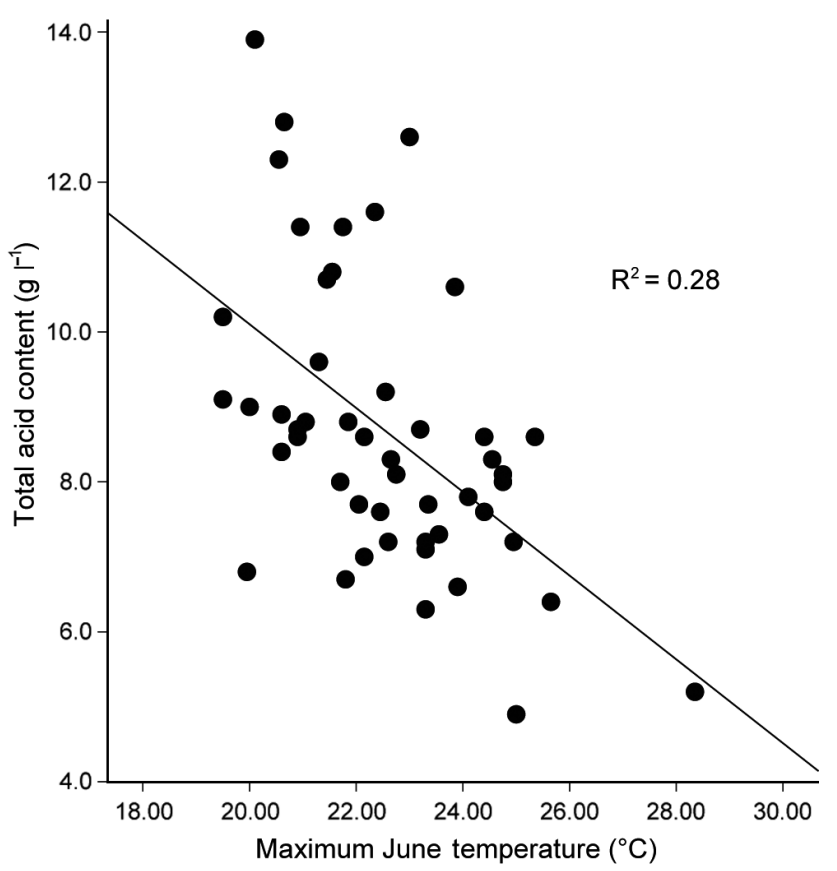

Fig. 5. Relationships between acid content at Bürgerspital and maximum June temperature. Regression line superimposed
In our study, the advance in budburst was too small ( 1 to $2 \mathrm{~d}_{\text {decade }}{ }^{-1}$ ) to achieve significance. The average dates for full flowering advanced 3 to $4 \mathrm{~d}$ decade $^{-1}$. Véraison showed the strongest trend in time, advancing $\sim 4$ to $6 \mathrm{~d}$ decade $^{-1}$. Harvest dates at the LWG showed similar trends in time starting $\sim 4$ to $5 \mathrm{~d}$ earlier per decade. Beginning of harvest at the Bürgerspital started $\sim 2 \mathrm{~d}$ earlier per decade. For budburst and full flowering, all 3 cultivars had similar mean onset dates; however, Müller-Thurgau grapes were the earliest to reach véraison and harvest. The apparent difference of harvest dates between the different locations is due to the fact that the Bürgerspital recorded harvest dates for the whole winery, including all cultivars and vineyards.

However, as Menzel et al. (2006) explained, harvest may need to be considered carefully since they are known as a false phase (Schnelle 1955). Harvest dates are based on subjective evaluations of optimum fruit composition. Thus, grape ripeness and therefore the beginning of harvest is based on both human judgment and on trends concerning the relative amounts of sugar and acid found in the grapes. However, the advances in $60^{\circ} \mathrm{Oe}$ sugar content suggest that grapes are ripening earlier and that advances in harvest dates are largely due to earlier maturity.

Jones \& Davis (2000) found significant decreasing trends over time for phase intervals from flowering to véraison, flowering to harvest, and véraison to harvest ranging between 4 and $10 \mathrm{~d}$. In our study, a significant shortening of phase intervals of some cultivars was observed, including full flowering to véraison for Riesling and Silvaner (Fig. 3) ( 2 to $3 \mathrm{~d}$ ) and budburst to harvest for Silvaner ( $\sim 3 \mathrm{~d})$. The budburst to full flowering interval shortened by $\sim 1$ to $2 \mathrm{~d}$ decade $^{-1}$, though only that for Silvaner at Bürgerspital was significant.

There were no significant differences between cultivars in trends or between Silvaner records from the 2 data sources. Similarity in the responses of the cultivars and at the 2 locations can therefore be seen as being characteristic for this northern part of the wine-growing area in Europe.

\subsection{Influence of climate}

Phenological events and composition were significantly influenced by the climate of preceding months (Table 4), especially during the growing season. Maximum temperatures proved to be the most influential climate parameter at this timescale. Precipita- 
tion and sunshine were significant in only certain cases and typically at lower levels of significance. Thus, the finding that temperature is the major driver of phenological shifts in grapevine (Rosenzweig \& Casassa 2007) was confirmed in this study. Due to the high number of potential climate variables (particularly for the later events and for the composition) some predictors may appear in the final regression models by chance alone, and due to their collinearity some months may be left out (e.g. March temperatures for LWG budburst). However, despite this caveat, it is clear that, under current climate conditions, mean maximum temperature was the major driver of phenology and composition.

Budburst was related to preceding maximum temperatures, and precipitation in April had a less significant impact only for the LWG cultivars, whereas sunshine had no significant effects. Other studies have reported that budburst also depends on soil temperature and pruning (Duchêne et al. 2010).

In comparison to Jones \& Davis (2000), flowering did not show any significant relationship with precipitation or hours of sunshine during the pre-flowering period. The former may be because the area of Lower Franconia is less water limited in summer than the Bordeaux region where Jones \& Davis (2000) based their study. Sunshine hours only had an impact on the Bürgerspital flowering dates, though at a lower level of significance and during the pre-budburst period. The reasons for the apparent differences in the influence of sunshine are unclear. The timing of events may be critical with day lengths increasing to the summer solstice (June 21) and declining thereafter. The influence of day length may be more critical at the northern limits of grape production. Another reason might be the use of different grape cultivars.

Véraison was also highly responsive to temperature. Müller-Thurgau, the earliest cultivar to reach véraison, was more dependent on temperature from April to June while Riesling, being the last, was related to temperatures in later months (May to July).

Harvest date models were more complex, but may be explained by the high number of potential climate variables and by harvest being a quasi false phase, which is based on both subjective evaluation and optimum fruit composition. On the other hand, advances of the date on which the sugar content exceeded $60^{\circ} \mathrm{Oe}$ suggest that grapes are ripening earlier. Thus, advances in harvest dates are largely due to earlier maturity. The advance of harvest dates is more likely to benefit Riesling and Silvaner, since they are late maturing cultivars.
Cool conditions have ensured that most Franconian vineyards are situated on south- or west-facing slopes along the Main River to obtain maximum heat and light exposure (Jackson 2000). Under global warming, temperature will not be such a limiting factor for wine-growing in Franconia and therefore vineyards could expand to other, formerly unsuitable, sites.

Though predictions about future precipitation and its distribution are imprecise, precipitation is likely to increase in winter and decrease in summer (IPCC 2007). Increasing dryness in summer, intensified by higher temperatures and greater evaporation might lead to water supply becoming an occasional limiting factor.

Warmer climatic conditions also favour the spread of grapevine pests and pathogens such as grape moths (Eupoecilia ambiguella and Lobesia botrana) and downy mildew (Plasmopara viticola), which are the main pest and disease in southern German vineyards (Kast 2001).

Due to the absence of gridded daily observations, other climate variables, including growing degree days (Mullins et al. 1992), number of days with high temperatures (Jones \& Davis 2000, Duchêne et al. 2010) and numerous indices (Jones \& Davis 2000, Malheiro et al. 2010) could not be used in this study. This might result in slightly different results of predictors in our regression models in comparison to other long-term studies.

\subsection{Composition}

The main features that German wine-growers working at the northern limits of viticulture have tried to achieve include late-budding - which reduces the likelihood of late spring frost damage-early maturing, high yield, high quality, and a good balance between acidity and sugar.

Jones \& Davis (2000) found for the Bordeaux region that acid levels displayed significant downward trends, while sugar levels showed no trends. In contrast, Urhausen et al. (2011) found for the Mosel Valley, a region $\sim 240 \mathrm{~km}$ west of Würzburg, significant downward trends in acid while sugar displayed significant upward trends. These findings are in line with Duchêne et al. (2010) who stated for the Alsace region that increasing temperatures will result in increasing sugar contents while acid levels decline. In our study, sugar content had a highly significant upward trend by $2.4^{\circ} \mathrm{Oe}$ decade $^{-1}$ while the acid concentration displayed no significant trend. Sugar 
content was significantly dependent on temperature during pre-flowering (i.e. April and May) and preharvest (i.e. August and September). In contrast, July precipitation had a positive effect on acid (i.e. an increase of acid content) while September sunshine decreased the acid concentration. Sugar content also showed large negative correlations with the phenological onset dates of flowering, and beginning and end of harvest. Furthermore, sugar and acid levels were negatively correlated with one another. Years of higher than average sugar had lower than average acidity. This means that warmer seasons with advanced phenology produce higher sugar levels and lower acid levels at harvest.

As a result of climate change, extreme heat during maturation may lead to an acceleration of ripening, a much quicker decomposition of acid and an increase of sugar content, resulting in higher alcohol levels or high contents of residual sugars but with little acidity retained for freshness and longevity. This in turn will lead to the loss of the typical balanced composition of wines of the northerly located wine-regions (Duchêne et al. 2010).

\section{CONCLUSIONS}

The findings confirm a consistent relationship between onset dates of phenological phases of all 3 cultivars and corresponding climate data. Mean maximum temperature was the most important factor while precipitation and sunshine were generally less influential. This may be because the region is not currently water limited.

The observed warmer seasons have resulted in greater ripening potential for Müller-Thurgau, Riesling and Silvaner grapes. As a consequence, the sugar content increased while the acid component remains constant, resulting in a changed grape composition that has the potential to alter wine typicity and quality. Given that climate is projected to change even further in the future, these impacts are expected to continue and to become stronger. Thus, in the long term, the balanced ratio of sugar and acid content will shift in favour of the sugar component and may result in a loss of the traditional character of white wine produced in Franconia.

With increasing temperatures the cultivation of early maturing cultivars might become problematic in Franconia. Increased temperature has advanced harvest dates and increased sugar content. This decreases the acid content and might have a negative impact on the typicity and aging ability of the pro- duced wine. The practice of acidulation, which is currently only allowed in extreme years with special authorisation, might become more frequent.

Moreover, Franconia is an historical wine-producing region, and the economic and cultural identity of Franconia is shaped by its wine and wine-growing tradition. Thus, the characteristic cultural landscape that has developed over the last millennium will likely be vitally affected by the potential impacts of climate change.

Acknowledgements. We thank the German Meteorological Service (DWD) for providing climate data, the Regional Office for Viticulture and Horticulture (LWG), especially Mrs. P. Hoenig, Mr. H. Schmitt and M. Pfeiffer, and the Bürgerspital zum Heiligen Geist in Würzburg, for providing phenological data. We thank the editor and referees for comments on an earlier version of this manuscript. The authors gratefully acknowledge the support by the Faculty Graduate Center Weihenstephan of TUM Graduate School at Technische Universität München, Germany and the Technische Universität München - Institute for Advanced Study, funded by the German Excellence Initiative.

\section{LITERATURE CITED}

Conde C, Silva P, Fontes N, Dias ACP and others (2007) Biochemical changes throughout grape berry development and fruit and wine quality. Food 1:1-22

de Orduna RM (2010) Climate change associated effects on grape and wine quality and production. Food Res Int 43:1844-1855

Draper NR, Smith H (1998) Applied regression analysis. Wiley, New York, NY

Duchêne E, Schneider C (2005) Grapevine and climatic changes: a glance at the situation in Alsace. Agron Sustain Dev 25:93-99

> Duchêne E, Huard F, Dumas V, Schneider C, Merdinoglu D (2010) The challenge of adapting grapevine varieties to climate change. Clim Res 41:193-204

> Hall A, Jones GV (2010) Spatial analysis of climate in winegrape-growing regions in Australia. Aust J Grape Wine Res 16:389-404

IPCC (2007) Climate change 2007: impacts, adaption and vulnerability. Contribution of Working Group II to the Fourth Assessment Report of the Intergovernmental Panel on Climate Change. Cambridge University Press, Cambridge

Jackson RS (2000) Wine science: principles, practice, perception. Academic Press, San Diego, CA

Jones GV, Davis RE (2000) Climate influences on grapevine phenology, grape composition, and wine production and quality for Bordeaux, France. Am J Enol Vitic 51:249-261

> Jones GV, White MA, Cooper OR, Storchmann K (2005) Climate change and global wine quality. Clim Change 73:319-343

Jorquera-Fontena E, Orrego-Verdugo R (2010) Impact of global warming on the phenology of a variety of grapevine grown in southern Chile. Agrociencia 44:427-435

Kast WK (2001) Twelve years of practical experience using mating disruption against Eupoecilia ambiguella and 
Lobesia botrana in vineyards of the Wuerttemberg region, Germany. IOBC WPRS Bull 24:71-73

Lisek J (2008) Climatic factors affecting development and yielding of grapevine in central Poland. J Fruit Ornam Plant Res 16:285-293

Meier U (1997) Growth stages of mono-and dicotyledonous plants. Blackwell, Berlin

Malheiro AC, Santos JA, Fraga H, Pinto JG (2010) Climate change scenarios applied to viticultural zoning in Europe. Clim Res 43:163-177

Menzel A, Von Vopelius J, Estrella N, Schleip C, Dose V (2006) Farmers' annual activities are not tracking the speed of climate change. Clim Res 32:201-207

Mullins MG, Bouquet A, Williams LE (1992) Biology of the grapevine. Cambridge University Press, Cambridge

Robinson J (2006) The Oxford companion to wine. Oxford University Press, Oxford

Rosenzweig C, Casassa C (2007) Assessment of observed changes and responses in natural and managed systems. In: Parry ML, Canziani OF, Palutikof JP, van der Linden PJ, Hanson CE (eds) Climate change 2007: impacts,

Editorial responsibility: Mauricio Lima, Santiago, Chile adaptation and vulnerability. Contribution of Working Group II to the Fourth Assessment Report of the Intergovernmental Panel on Climate Change. Cambridge University Press, Cambridge, p 79-131

Schnelle F (1955) Pflanzenphänologie. Akademische Verlagsgesellschaft, Leipzig

Unwin T (1991) Wine and the vine: an historical geography of viticulture and the wine trade. Routledge, London

Urhausen S, Brienen S, Kapala A, Simmer C (2011) Climatic conditions and their impact on viticulture in the Upper Moselle region. Clim Change, doi:10.1007/s10584-0110059-z

van Leeuwen C, Friant P, Chone X, Tregoat O, Koundouras S, Dubourdieu D (2004) Influence of climate, soil, and cultivar on terroir. Am J Enol Vitic 55:207-217

Webb LB, Whetton PH, Barlow EWR (2007) Modelled impact of future climate change on the phenology of winegrapes in Australia. Aust J Grape Wine Res 13:165-175

Webb LB, Whetton PH, Barlow EWR (2011) Observed tends in winegrape maturity in Australia. Glob Change Biol $17: 2707-2719$

Submitted: May 11, 2011; Accepted: August 30, 2011

Proofs received from author(s): November 21, 2011 